\title{
MODERN CATHOLICISM AND FEMALE IDENTITY
}

\author{
Religious identity in contemporary society
}

\section{Authors: Johannes Aengenheyster \& Caitlin Masoliver}

\begin{abstract}
This research explores the experiences of young Catholic women in contemporary Western European society. Using qualitative research methods, several in-depth interviews reveal how young Catholic women's identities are structured and negotiated within an increasingly secularized society. It shows that young women today emphasize values of tolerance and indiscriminate love over traditional Catholic teachings. Furthermore, community serves as an important frame of reference for their religious engagement. The findings offer interesting comparisons and contradictions to the existing literature in the field.
\end{abstract}

\section{Introduction: Religion in the context of a secularizing society}

In the last fifty years, Western Europe has seen an unprecedented rise in secularisation. There are more agnostics and atheists than there are religious people in Britain; 70\% of Dutch people do not identify as religious (Zuckerman, 2016). Religion and religiosity are in decline, and it is becoming increasingly unusual for younger generations to adopt such strong religious beliefs as their ancestors (Zuckerman, 2016). According to Haynes (1997), major societal changes of increasing democratization and individualization from the 1960's onwards began 
this process of secularisation. Individuals born in the later years of the $20^{\text {th }}$ century experienced more secular societal norms, and consequently have a higher chance of leaving or being absent from the church. There are, however, still a high number of individuals who identify themselves as religious, something becoming increasingly difficult as secularisation increases. Not only are religious believers confronted with a society growing ever more dubious and hostile towards their faith, but they are presented with social values and ideas that contradict those they have been taught by their religion. Especially when considering gender and religion, improvements in socio-economic and legal equality of the sexes on the societal level have not led to a similar reform of traditionally patriarchal Catholic dogma and formal teachings, with women limited to lay positions rather than clergy (Ozorak, 1996). In an increasingly secular society with hostile views and stereotypes of religion, it is relevant to explore how younger individuals following Catholicism experience their identity and conception of self, to uncover lived experiences beneath these stereotypes and further explore the paradoxical relationship between society and church tradition. In doing so, one can add work to the concept of secularisation, and see how, despite this, religion persists in the modern world. According to Fearon (1999), an individual's identity is formed by labels and rules that mark individuals as members of one social category or group, and by the characteristics a person takes pride in. Using this definition, this research explores young Catholic's experiences of their identity within the social group of their religion, and the personal values and meaning surrounding their faith. The research question was thus formulated as "How do young Catholic women experience and define their religious identity within an increasingly secularized Western Europe?". To answer this, the paper begins with a literature review on contemporary and female religiosity. It then addresses the methodology used to conduct the research. The two main themes which encompass our findings are then presented, the first referring to the heightened importance of values over teachings for participants, and the second addressing the significant role of community in their faith. These two themes are indicative of the paper's core finding that there is a decrease in the importance of institutionalized elements of religion and an increase in a more self-reflective, inclusive experience of religious identity.

\section{Literature Review}

The body of research around the topic of women and religion is becoming increasingly of interest to the scholarly community. Regarding Christianity, one explanation of this could be due to a trend that women, regardless of their age, 
outscore men on all levels of religiousness. Women are more likely to pray, attend church, participate in religious organised events, and to claim that their religion is important to them (Trzebiatowska \& Bruce, 2012). This is especially interesting considering that Christianity is, typically, patriarchal and therefore inhospitable in their teachings and beliefs surrounding participation of women, such as their exclusion from the clergy. Ozorak (1996) has explored this paradox between female experience of traditional religious teachings and their own perception of their rights and place in society. As they face prejudice in every "fibre of the religious establishment" (Ozorak, 1996, p. 17), empowerment of women within the Church is difficult. She shows that women, in order to cope with underlying gender inequalities of the Church, experience faith in terms of relationships and community, rather than perceiving it in terms of hierarchy and power. The Church community, mostly built of and by women over decades, is supportive in cases of personal difficulties, by allowing women to work together and form close relationships with their surrounding community (Ozorak, 1996).

Another important element of personal identity refers to one's experiences of their sexuality. Women's experiences of their sexuality have been shown to be conflictual with modern Catholicism in an increasingly secular and open society. As the Catholic Church continues to use binary distinctions for genders and their roles, men and women are seen to differ on essential biological and spiritual levels (Becher, 1991). This is manifested in an affirmation of so-called traditional gender roles, according to which men are active, assertive and providing, while women are emotional and caring. This gendered differentiation is seen as resulting in a complementary drive to the loving, natural union of marriage. Consequently, the doctrine condemns a variety of sexual practices that counteract the "divine law", such as those that are individual (masturbation), homosexual, without love (prostitution), extra-institutional (premarital), evade procreation (contraception), or deny marital fidelity (adultery) (Becher, 1991). To what extent this influence manifests into shaping the identity, sexual behaviour, and principles of its followers is unknown. This introduces an interesting gap for exploring to what extent the Church shapes female sexual identity, and their perceptions to sexual-related topics such as homosexuality and contraception.

From an historical perspective on gender, sexuality, and the role of family in the Church, Wuthnow (2010) suggests that the Catholic Church is experiencing a "crisis in institutions". This holds that the majority of its community involvement revolves around early marriage and families with children, which is based on the society of the 1950s. As the Church has not adapted to the prolonged emerging adulthood of contemporary society, for example by addressing the trajectories of singles and couples without children, it has lost much of its younger 
membership. Its focus on sexual ethics rather than other issues felt to be more important, such as social justice, means it is becoming increasingly irrelevant in the lives of potential younger followers (Dillon, 1996).

\section{Methodology}

The nature of gathering data for our research consisted of interviews, with one researcher interviewing each participant individually. Participants consisted of female students at Maastricht University identifying as Catholic. In terms of the age demographic, the literature review exposed interesting information on young adolescents and teenagers practicing religion in modern society. For newer generations, the traditional teachings of the Church are seen as "out of touch" with the problems that they perceive as more important, and irrelevant to the society in which they live (Wuthnow, 2010). Furthermore, as students ourselves, it felt easier to connect with individuals of a similar age.

To find participants, we first posted on Facebook for potential participants, approached fellow students who expressed interest, then contacted a student chaplaincy in Maastricht. This chaplaincy is organized by a group of Sisters who hope to create a "safe-space" for young Catholics to discuss and share their religion, forming a close community away from the potential judgement from society. We attended mass followed by several dinners hosted by the Sisters, and through this channel met and spoke with students who might be interested in participating in our research. We contacted participants found on each of these platforms for further interviews by which data was collected directly. While initially participant observation was planned to be used for gathering data, the Sisters expressed concern about making students attending the dinner uncomfortable. We therefore used the Church visitations as a platform for building rapport and relationships with potential participants.

The interviews were conducted over a four-week period, and after gaining informed consent from participants, lasted between thirty minutes to one hour. In total, seven individuals were interviewed. An overview of the participants can be seen in Table 1; pseudonyms were used in the transcribing process to protect the anonymity of participants, thus names referred to hereafter are fabricated.

The nature of the interviews was holistic and semi-structured. The general themes for the interviews were planned and inspired by content of the literature review, and a list of preliminary questions was made under each theme. These themes entailed first a general background and upbringing of the individual, followed by the role of religion in their childhood, the role of religion during 


\begin{tabular}{llr}
\hline Name of participant & Country of origin & Age \\
\hline Alexandra & Germany & 20 \\
Amy & Germany & 22 \\
Catherine & Germany & 22 \\
Jane & The Netherlands & 20 \\
Patricia & The Netherlands & 23 \\
Rachel & Mexico & 24 \\
Sarah & England & 20 \\
\hline
\end{tabular}

\section{Table I Summary of the participants}

their transition to University and living away from home, their experience of platonic and sexual relationships, and ending with the most pivotal elements of religion for them personally. The recorded interviews were transcribed, and coded according to themes highlighted in the literature review and to other themes that emerged throughout the conversations. These codes highlighted the main themes in the research that emerged through each of the interviews, two of which will be elaborated on in the body of this paper.

\section{Theme I: Values over teachings}

An idea present throughout the interviews was the women's focus on what they classified as "values", rather than "teachings" often associated with the Catholic Church. When speaking of values and teachings, the interviewees had a shared, albeit implicit, definition; teachings referred to rules, based on dogma, that individuals are told to live their lives by, such as "no sex before marriage", or prohibiting homosexuality, and rituals such as praying before bed and attending Church every Sunday. Contrasted with these teachings were more general values, fundamental to one's character and manifested in their behaviour, such as being indiscriminately kind and tolerant towards others. For example, Rachel refers to these as "little decisions everyday where you can feel the religion"; Amy refers to "Christian values, like respect and love and whatever...don't kill, don't hurt, don't judge"; Sarah says it "is a very Christian thing to do, putting others before myself". Though varying in degree, all participants considered the way one chooses to live one's life and the principles behind these decisions more valuable than rituals and dogmatic teachings. Whilst the values were spoken of highly by participants, "teachings" were more oppressive, and less important to follow. 
Contraception, abortion, and sex before marriage were mentioned by several participants as teachings they had chosen not to implement in their life. When referring to the work of Becher (1991) discussed in the literature review, this suggests that traditional Catholic teachings are losing relevance and therefore have a reduced influence on young Catholic's construction of their identity.

Furthermore, the anti-homosexuality teaching for example was seen as unnecessary and outdated by all participants, and several spoke of hope for future progression and change. Equal participation was regarded as far more important than the more exclusive traditional teachings, which several participants termed superfluous and lacking justification. This was less the case for one interview participant from Mexico (Rachel), who was more cautious when criticising the Church's teachings, however she also expressed hope for change. How one feels towards traditional teachings on homosexuality was discussed by Jane as the choice of the individual, and not the choice of the people making up the Church, or those who wrote the Bible. A divisive line between values and teachings was thus seen as present throughout the discourse of the participants. "Oppressive", "restrictive", and "exclusive" are just a selection of the language in the discourse around traditional teachings, suggesting that for young contemporary Catholics, their identity is influenced less by the institutional rules of the Church, and constructed more around self-reflective values that the individual considers important on their own.

The distinction between values and principles held by the individual and what is officially taught by the Church as right and wrong is also discussed by Amy. She speaks of how she rejects being told "you can't do this", or "this should not be", saying it is "something that [she doesn't] participate in", as she does not understand its purpose. For her, the idea of Catholicism as a safe place allowing for indiscriminate participation holds more significance than the Churches directions and teachings, reflected also by Rachel who argues that "God cannot be exclusive". This illustrates how, for modern Catholicism, religious identity and what individuals derive as the meaning of their religion is far less related to the dogma and formal teachings of the institution, and moving more towards a progressive, inclusive, and individually driven ideology.

Sarah speaks most explicitly on the distinction between personally derived values, and teachings from authority figures. She reflects on her experience of dealing with conflict between her own values, and what the Catholic Church teaches as right and wrong. She suggests, almost with an ironic undertone, that if the ritualistic praying before bed, saying grace before meal time, and going to Church every Sunday is what truly makes one a Catholic, she is "a really shit Catholic". Sarah follows by making a conscious division between her own beliefs and the teachings of the "Catholic religion" as "two different things". In mentioning that in choos- 
ing not to follow the instructed teachings of the Catholic Church, Sarah highlights the idea that this makes her by definition, a "shit Catholic". Her beliefs and values derived from her religion are viewed as something separate to the direct teachings of Catholicism, and this is a separation she has made consciously in her mind. This discourse of not following the teachings of Catholicism making one a bad Catholic is also present in the interview of Jane and Amy. This, however, was said in all cases with a light-hearted tone, illustrating their apathy towards this suggestion. Although drawing from a small sample size, the overall theme of values in relation to teachings throughout the interviews conducted was that, for these women, the teachings of Catholicism are not as relevant as they were before. Both Sarah and Jane explained their disagreement with the Church's teachings on sex, contraception, and marriage to living in a more modern era where premarital and homosexual sex is less disapproved of by society. What took priority were the innercore principles one holds, the desire to do good and to help others. Amy, for example, speaks of how "constricting" she finds the Church's teachings, and that for her own experiences, to focus on her own values of being a good person to others was the most important element of her belief. This supports the claim of the paper that for modern Catholicism, one's religious identity is decreasingly built on the rituals and dogma of the church institution, and more on the individual's self-reflection and personal idea of morality.

One explanation of the decline in importance of traditional teachings may be due to their decreased relevance for young adolescents. According to the research of Walter and Davie (1998), for modern Catholic women the more traditional teachings are losing relevance and significance, as they are confronted with societal values and norms that differ with that of their religion. Sarah reflects this idea, stressing that due to "living in the 21st century", her experience will differ greatly from that of her parents, as the context surrounding what is appropriate is so different. Throughout all the interviews, there was a common idea expressed that the Church as an institution had little influence over the values participants felt were important. There was an explicit reference in both Jane's and Rachel's interviews that individuals in high-level positions in the Church are not dictating what they take out of their religion and implement into their lives. The Church as an institution is almost brushed aside when it comes to the individual's decision to implement teachings, and is certainly criticised for its dogmatic style. A more reflective, spiritual focus on values fundamental to one's character as a 'good person' takes higher priority. Considering the centrality of the Vatican in shaping Catholicism officially, this idea is interesting as on the micro-level it reflects a declining importance of traditional dogma, and a more self-reflective and autonomous decision over the values one deems part of their identity. 


\section{Theme II: Community structuring religious identity}

All women mentioned the importance of community in the interviews. Furthermore, all participants describe community as positive, since it supports their well-being and the practice of their faith. In line with this, they did not recount many negative experiences from their religious environment, such as peer pressure or being forced to attend Church by parents or relatives against their will. Overall, our findings are very much in line with Ozorak's (1996) argument that women, as a response to unequal official structures of the Church in a society with increasingly equal status of men and women, view the Church in terms of community, rather than hierarchy. Regarding women's exclusion from the clergy, Patricia, reduces their importance by stating that "[she] simply [doesn't] care very much", although she also describes herself as "[being] all for women's rights, and equality, and gender based stuff". What is emphasized instead is indeed the social environment of Catholicism, for example when Alexandra states that "it's the people who make up the community and not the priest". This emphasis on community, rather than hierarchy, holds true for all participants. However, more patterns in regard to community can be seen when comparing the life trajectories of the women. Table 2 shows that participants can be classified based on whether or not they grew up in a religious household, and whether they are actively practicing at the time of the interview (It is worth noting that such binary distinctions, while based on the data, are made for the sake of argument and not to claim that religious experiences can be reduced to dichotomous variables).

For the five women who grew up in practicing religious families and experienced religion in their upbringing, typical activities involved attending mass, praying at home (in the morning, before meals, or before bed), and reading the bible. Their parents were furthermore often involved in their respective parishes through maintaining friendships, holding social events, performing liturgical activities, and taking on organizational and financial tasks. Religion permeated their friendships and social activities: All of these women participated in religious group activities, such as the scouts, youth groups, altar service, church choir or pilgrimages, which offered ample opportunities for socializing. Amy thus states, referring to her childhood and early teens, that religion was "kind of dictating [her] social life for a while".

Of these five women, nobody except Rachel was still actively practicing. While it may seem contradictory that many who are not currently practicing still identify as Catholic, it indicates that experiences of religious upbringing leave long-lasting impacts that continue to shape identity even in absence of practice. 


\begin{tabular}{lll}
\hline & Practicing & Non-practicing \\
\hline Religious upbringing & Rachel & Amy \\
& & Sarah \\
& & Alexandra \\
& & Catherine \\
Non-religious upbringing & Jane & \\
& Patricia & \\
\hline
\end{tabular}

\section{Table 2 Categorization based on upbringing and current practice.}

Their decline of faith was characterized by the absence of Church attendance and community involvement in Maastricht. The importance of religiosity in guiding their life after moving out to enter university or to do voluntary work decreased as well, exemplified by Amy's description of herself as "currently more atheist than Catholic". Meanwhile two of the three individuals actively practicing their religion had grown up in households that did not place much emphasis on a religious upbringing. Rachel, the Mexican student, is an outlier in both cases, and indicates that these trends are specifically situated in Western Europe.

In order to analyse these different life courses, the role of religious community in socialization and identity formation is worth investigating. Wuthnow (2010) observes that historically and contemporarily, the community focus of the Catholic Church is fundamentally linked to the nuclear family life. This is supported by the interviewees. While the Catholic Church provides many activities and involvement that appeal to children and adolescents and parents, it lacks possibilities to engage other demographics, including young adults. This is indicative of both social change, as the period of emerging adulthood has greatly increased, as well as stagnation of Catholic community focus. This means that the traditional institutions of Catholic socialization become increasingly ineffective, since the identity fostered by a Catholic upbringing contrasts so much with that of young adult life that the former is often abandoned.

Furthermore, and in line with this, it seems that the community focus becomes the constitutive element of religion, which explains the decrease of religiosity as women leave their religious families and communities. Amy supports this interpretation, discussing how she "used to be devout mainly because of the structure of it, [she] wasn't truly a believer, it was more like because it was comforting and [she] had friends", and accounting her loss of such strong Catholic faith to the fact that "all the good parts of it were falling apart...my family wasn't with me, and [neither were] my friends". In contrast to this, the women that became more involved with religion later in their life obviously lack such 
community experiences during childhood. On from when they started practicing religion in their teenage years, community involvement constituted only one of the reasons live a religious life. Jane even explicitly denies that community played a role in her transformation process, stating how she would go to Church "just for going there, purely, for the religious reason, and not necessarily because of the community". This is not to say that these women do not value community, as they still describe social engagements in the chaplaincy, in their parishes or at mass events in a very positive tone. Consequently, their faith is a "combination of more elements [than community]" (Jane), such as the personal conviction of the meaningfulness of religion, which is not effectively conveyed through the institutions of religious socialization in Catholic households and communities.

Another difference between the women which grew up religiously and those which became involved only later in life is that the former see religious community primarily in non-religious terms. Amy describes her experience of the World Youth Day 2011 in Madrid, while labelling it her "best religious memory" without using religious vocabulary: "My friends and I were just like running around the city and with like our flag, and met other people and took loads of pictures with random people who also had flags from different countries". While the event is obviously a religious one, the lack of religious terminology makes it resemble other popular large scale social events, for example a music festival or concert. Meanwhile the women who discovered religion later in life and see community as one element among others, value it differently by attaching an explicit religious dimension to it: Jane, recounting the World Youth Day in Krakow in 2015 as a formative event of her religiosity, sees a spiritual element in her connection to other people: "you could really feel that there was [...] like the 'presence of God', [...] it connected all of us". Besides varying depth of internalization of religious identity, it is shown again that it is barely constituted through traditional formal religious structures, as a more personal understanding comes to the fore.

\section{Conclusion}

This research illustrates a trend that the importance of institutionalized elements of religion are decreasing, and a more self-reflective, inclusive experience of identity is growing. This is reflected first in the importance of individual values inherent to one's character as a 'good person', rather than on the traditional teachings so often associated with the institutional structure of the Catholic Church. It is further reflected in the experience of religion through the lens of community, where acceptance and indiscriminate love are pivotal, rather than the tradition- 
ally hierarchical and patriarchal institutional structure. This research brings new work to the field of religious studies and sociology, and challenges pervasive stereotypes in society of Catholicism as anti-progressive, homophobic, and highly dogmatic. This is of interest for both researchers in the field of religious studies, but also for the wider audience of believers and atheists alike. By shedding light on some aspects of Catholicism in contemporary society, this research proposes new avenues for future research. The phenomena of young individuals getting more religious, the inclusion of religion in everyday life, and mechanisms of coping with stereotypes are all interesting grounds for further investigation.

\section{References}

Becher, J. (1991). Women, religion, and sexuality: Studies on the impact of religious teachings on women. Philadelphia: Trinity Press International.

Dillon, M. (1996). The persistence of religious identity among college Catholics. Journal of Scientific Study of Religion,35(2),165-170. doi: 10.2307/1387083

Fearon, J. (1999). What is identity (as we now use the word). Unpublished manuscript. Stanford University, Stanford,Calif.

Haynes, J. (1997). Religion, secularisation, and politics: A postmodern conspectus. Third World Quarterly, 18(4), 709-728. doi:10.1080/01436599714722

Ozorak, E. (1996). The power, but not the glory: How women empower themselves through religion. Journal for the Scientific Study of Religion, 35(1), 17-29. doi:10.2307/1386392.

Trzebiatowska, M., \& Bruce, S. (2012). Why are women more religious than men? New York: Oxford University Press.

Walter, T., \& Davie, G. (1998). The religiosity of women in the modern West. British Journal of Sociology, 49(4), 640-660. doi:10.2307/591293

Wuthnow, R. (2010). After the baby boomers: How twenty-and thirty-somethings are shaping the future of American religion. Princeton University Press.

Zuckerman, P. (2016, December 05). Religion declining, secularism surging [Blog post]. Retrieved from http://www.huffingtonpost.com/phil-zuckerman/religion-declining-secula_b_9889398. html 